
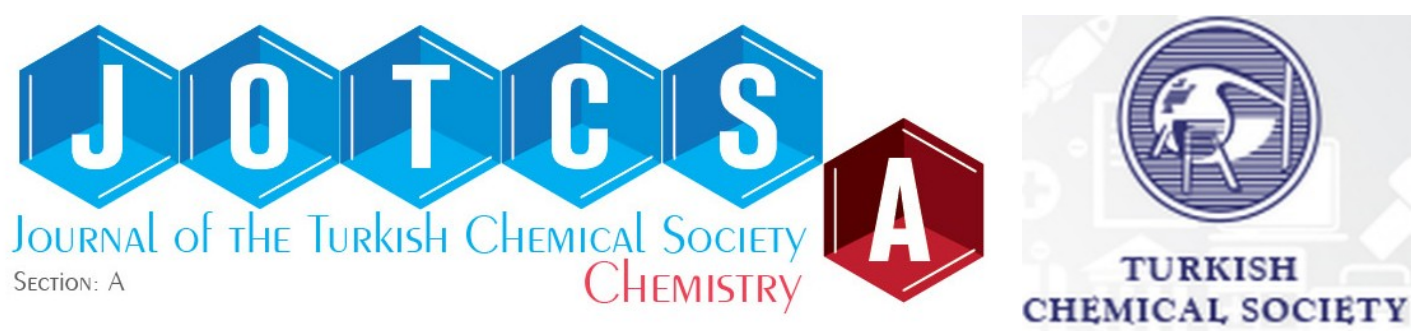

\title{
Synthesis of Tricyclic Quinoline Derivatives from 5- and 6- Aminoindazoles and 5-Aminoindole under Conventional Way and Microwave System
}

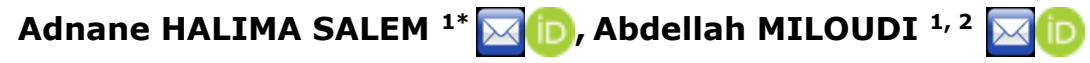 \\ ${ }^{1}$ Fine Chemistry Laboratory, Chemistry Department, Faculty of Exact and Applied Sciences, University \\ Oran 1, BP1524, El Mnaouer, 31100, Oran, Algeria \\ 2 Department of Preparatory Classes in Science and Technology, National Polytechnic School of Oran \\ Maurice-Audin, BP1523, El Mnaouer, 31100, Oran, Algeria
}

Abstract: Targeted tricyclic quinolines were prepared from the corresponding aminoindazolic and indolic
derivatives as starting materials using two comparative methods; conventional heating and microwave
irradiation. We noticed that the syntheses of 5 -amino-1-methylindazole and 5-aminoindole were
abandoned due to their conversion to fluorescent products one week after free contact with air and
acetone. As a result of this finding, we decided to condense the relevant amine with acetone or mesityl
oxide to confirm our hypothesis. We show that the amine is converted to the derived quinoline through
these condensation processes. Subsequently, this reaction was extended to the aminoindazole
derivatives of positions 5 and 6 , yielding the appropriate quinoline derivatives. Similarly, 5 -aminoindole
exhibited the same reactivity. By applying the corresponding NMR and centesimal techniques, the
resulting structures were identified.

Keywords: 5- and 6- aminoindazole, 5-aminoindole, quinoline, acetone, mesityl oxide.

Submitted: March 29, 2021. Accepted: June 02, 2021.

Cite this: Halima Salem A, Miloudi A. Synthesis of Tricyclic Quinoline Derivatives from 5- and 6Aminoindazoles and 5-Aminoindole under Conventional Way and Microwave System. JOTCSA. $2021 ; 8(3): 811-20$.

DOI: https://doi.org/10.18596/jotcsa.904598.

\section{${ }^{*}$ Corresponding author. E-mail: 221halimasalem.adnane@gmail.com.}

\section{INTRODUCTION}

Throughout this century, significant research has been conducted on the synthesis and development of new heterocyclic compounds containing various heteroatoms, namely nitrogen, oxygen, and sulfur; the goal of this work is to produce products with active biological properties that are comparable to those found in nature (1-3). Indazole and quinoline derivatives are pharmacologically important, forming the basic structure of several drugs treating arthritis (4), gynecological disorders, anti-inflammatory (5), the derivatives of isoxazole, thiazoles, and quinoline cyanopyridine, have very good anticancer and antimicrobial activity (6-8). A brief overview of their general preparation methods is necessary; more detailed studies were conducted to synthesize derivatives of quinoline starting from a series of carbonyl (919), while scandium ion was used as a catalyst in place of iodine to modify the Skraup reaction in order to increase yield in less time when microwave irradiation was used (13). W.XiangShan and co-worker used a method to obtain quinoline derivatives via three-component reactions of aldehydes, aminoindazole, and thiopyranone (20); recently, a tetrahydro-3Hpyrazolo[4,3-f]quinoline core was synthesized using Povarov multicomponent reaction, the product's proof is its efficiency against cell cancer 
(21) (Figure 1), we were then interested on the simple, and eco-friendly methods. synthesis of these types of heterocycles with fast,
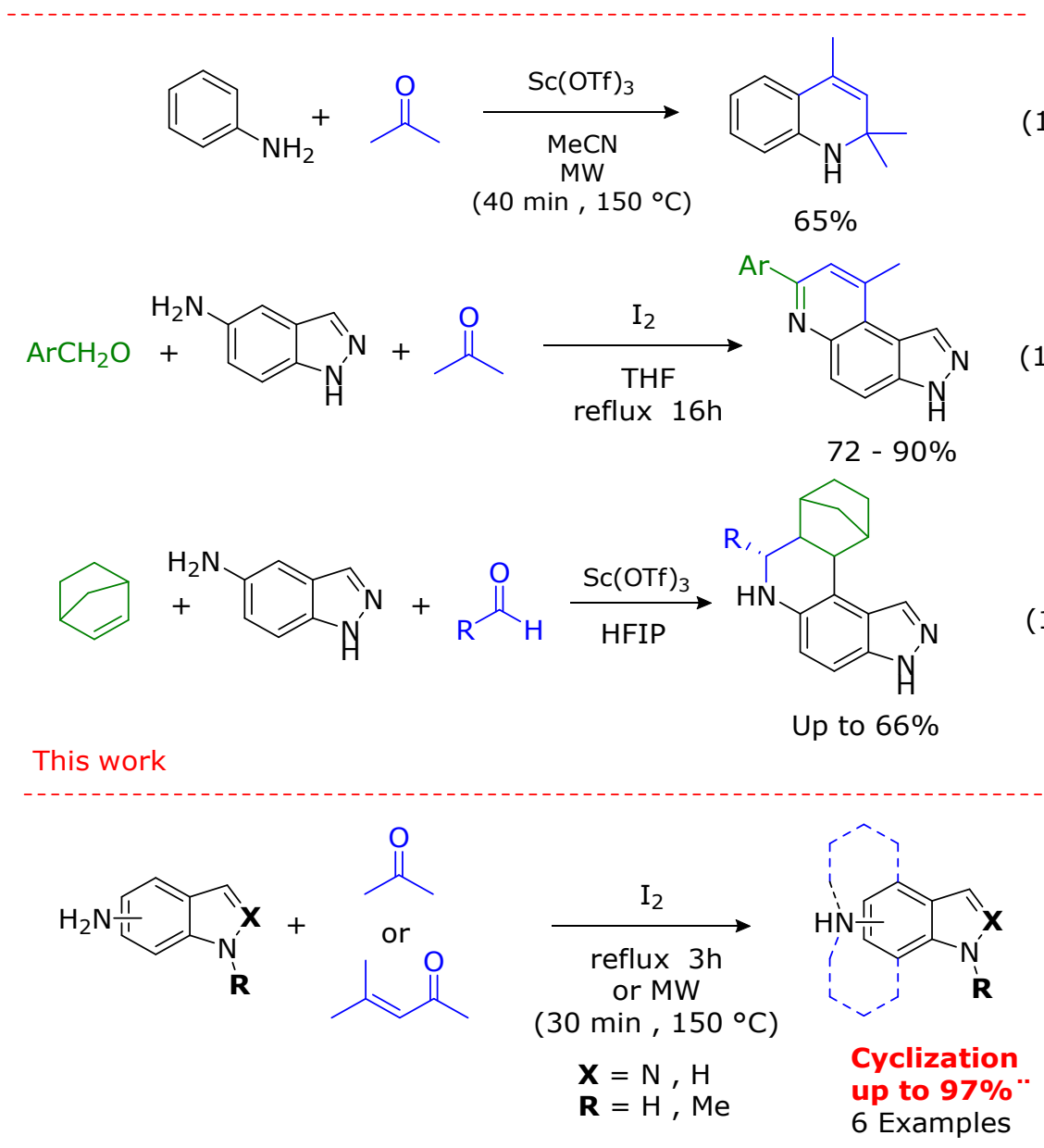

Figure 1: Similar reactions described in the literature.

\section{EXPERIMENTAL SECTION}

General Remarks: Melting points were measured on a Büchi Melting Point apparatus and are not corrected. Microwave reactor for microwaveassisted extractions: Monowave 450 from Anton Paar, The ${ }^{1} \mathrm{H}$ and ${ }^{13} \mathrm{C}$ NMR spectra were measured on a Bruker Avance 300 Spectrometer operating at $300 \mathrm{MHz}\left(300 \mathrm{MHz}\right.$ for ${ }^{1} \mathrm{H}$ and $100 \mathrm{MHz}$ for ${ }^{13} \mathrm{C}$ ). The chemical shift was recorded as units relative to DMSO- $\mathrm{d}_{6}$ or $\mathrm{CDCl}_{3}$ as the solvent unless otherwise stated, and $J$ values in Hertz. Combustion analyses were performed in the Microanalysis Laboratory of the National Center for Scientific Research in Vernaison in France. Separations by chromatography were performed with Merck on "silica gel 60 "(60 - 230 mesh).

\section{Condensation of aminoindazoles into quinoline Method a}

A dry $250 \mathrm{~mL}$ bi-necked flask was charged with $2.50 \mathrm{~g}(17.01 \mathrm{mmol})$ of 1 -methyl-5-aminoindazole, with $5 \mathrm{~mol} \%(0.215 \mathrm{~g}, 0.850 \mathrm{mmol})$ of iodine, into a solution of acetone of $200 \mathrm{~mL}$ (variable quantity according to the number of mole of amine used). The solution is carried under reflux for 3 hours, the solution was washed with water, the solvent was removed under reduced pressure, and the residue is purified by chromatography on a column with eluent: EtOAc / petroleum Ether $(1 / 1 \mathrm{v} / \mathrm{v})$.

\section{Method b}

In sealed tube charged with stirring bar, a solution of 5 -aminoindazole $(0.133 \mathrm{~g}, 1 \mathrm{mmol})$ in $5 \mathrm{~mL}$ of acetone was added 5 mol\% of iodine; the reaction mixture was heated at $150{ }^{\circ} \mathrm{C}$ with $400 \mathrm{~W}$ during $30 \mathrm{~min}$, the solution was washed with water the solvent was removed under reduced pressure, the residue is purified by chromatography on column with eluent: EtOAc / petroleum ether $(1 / 1 \mathrm{v} / \mathrm{v})$.

\section{Method c}

A dry $250 \mathrm{~mL}$ bi-necked flask was charged with an equimolar mixture of 1-methyl-5-aminoindazole $(2.50 \mathrm{~g}, 17.01 \mathrm{mmol})$ and of mesityl oxide $(1.67 \mathrm{~g}$, 
$17.01 \mathrm{mmol})$ with $5 \mathrm{~mol} \%$ of iodine $(0.215 \mathrm{~g}$, $0.850 \mathrm{mmol}$ ), in solution in $200 \mathrm{~mL}$ of acetone. The solution is carried under reflux for 3 hours. After filtration and evaporation, the residue is purified by chromatography on the column, eluent: EtOAc / petroleum ether (1/1 v/v).

\section{3,7,7,9-Tetramethyl-6,7-dihydro-3H-}

pyrazolo[4,3-f] quinoline I method $c$ :

$3.75 \mathrm{~g}, 97 \%$, method a : $1.33 \mathrm{~g}, 34 \%$, m.p. 148 ${ }^{\circ} \mathrm{C},{ }^{1} \mathrm{H}-\mathrm{NMR}\left(300 \mathrm{MHz}, \mathrm{DMSO}-\mathrm{d}_{6}, \delta, \mathrm{ppm}\right): 7.88$ $(1 H, s), 7.23(1 H, d, J=8.7 \mathrm{~Hz}), 6.76(1 H, d, J=$ $8.7 \mathrm{~Hz}), 5.72(1 H, \mathrm{~s}), 5.21(1 H, \mathrm{~s}), 3.92(3 H, \mathrm{~s})$, $2.19(3 H, \mathrm{~s}), 1.19(6 \mathrm{H}, \mathrm{s}) .{ }^{13} \mathrm{C}-\mathrm{NMR}(100 \mathrm{MHz}$, DMSO-d 6 ) $\delta: 138.7,135.1,130.3,128.9,127.6$ $(\mathrm{Ar}-\mathrm{C}), 120.7,116.5,109.4,109.2(\mathrm{Ar}-\mathrm{CH}), 50.7$ $\left(-\mathrm{NH}-\underline{\mathrm{C}}\left(\mathrm{CH}_{3}\right)_{2}\right), \quad 35.3\left(>\mathrm{N}-\mathrm{CH}_{3}\right), 29.7\left(2 \mathrm{x}-\mathrm{CH}_{3}\right)$, $21.7\left(-\mathrm{CH}_{3}\right)$. Anal. calcd for $\mathrm{C}_{14} \mathrm{H}_{17} \mathrm{~N}_{3}$ : C, 73.98; $\mathrm{H}$, 7.54; N, 18.49. Found: C, 73.39; $\mathrm{H}, 7.34 ; \mathrm{N}$, 18.52 .

7,7,9-Trimethyl-6,7-dihydro-3H-pyrazolo[4,3f] quinoline III, method b: $0,96 \mathrm{~g}, 45 \%$, method c : $(1.33 \mathrm{~g}, 10 \mathrm{mmol})$ of 5 -aminoindazole, mesityl oxide $(0.98 \mathrm{~g}, 10 \mathrm{mmol})$, iodine $5 \mathrm{~mol} \%$ and 100 $\mathrm{mL}$ of acetone: $0.6 \mathrm{~g}, 28 \%,{ }^{1} \mathrm{H}-\mathrm{NMR}$ (300 $\left.\mathrm{MHz}, \mathrm{DMSO}-\mathrm{d}_{6}, \delta, \mathrm{ppm}\right): 12.42(1 \mathrm{H}, \mathrm{s}), 7.69(1 \mathrm{H}$ s), $6.92(1 H, d, J=8.7 \mathrm{~Hz}), 6.47(1 \mathrm{H}, \mathrm{d}, \mathrm{J}=8.7$ $\mathrm{Hz}), 5.38(1 H, \mathrm{~s}), 4.94(1 H, \mathrm{~s}), 1.96(3 H, \mathrm{~s}), 0.94$ $(6 H, s) .{ }^{13} \mathrm{C}-\mathrm{NMR}\left(100 \mathrm{MHz}, \mathrm{DMSO}-\mathrm{d}_{6}\right) \delta: 139.5$, 138.6, 129.1, 127.3, 125.1 (Ar-C), 120.1, 116.7, 110.2, $109.2(\mathrm{Ar}-\mathrm{CH}), 50.8\left(-\mathrm{NH}-\underline{\mathrm{C}}\left(\mathrm{CH}_{3}\right)_{2}\right), 29.8$ $\left(2 \mathrm{x}-\mathrm{CH}_{3}\right), 21.7\left(-\mathrm{CH}_{3}\right)$.

(1,3-Dimethyl-buta-1,3-dienyl)-(1H-indazol5-yl)-amine IV, method $\mathbf{c}:(1.33 \mathrm{~g}, 10 \mathrm{mmol})$ of 5 -aminoindazole, mesityl oxide $(0.98 \mathrm{~g}, 10 \mathrm{mmol})$, iodine $5 \mathrm{~mol} \%$ and $100 \mathrm{~mL}$ of acetone : $0.51 \mathrm{~g}$, 24\%, ${ }^{1} \mathrm{H}-\mathrm{NMR}\left(300 \mathrm{MHz}, \mathrm{DMSO}-\mathrm{d}_{6}, \delta, \mathrm{ppm}\right): 12.66$ $(1 H, \mathrm{~s}), 7.95(1 \mathrm{H}, \mathrm{s}), 7.09(1 \mathrm{H}, \mathrm{d}, \mathrm{J}=8.7 \mathrm{~Hz})$, $6.57(1 \mathrm{H}, \mathrm{d}, \mathrm{J}=8.8 \mathrm{~Hz}), 5.50(2 \mathrm{H}, \mathrm{d}, \mathrm{J}=8.3 \mathrm{~Hz})$, $5.21(1 H, s), 4.89(1 H, d, J=5.1), 3.72(1 H, s)$, $3.33(3 \mathrm{H}, \mathrm{s}), 1.00(3 \mathrm{H}, \mathrm{s}) .{ }^{13} \mathrm{C}-\mathrm{NMR}(100 \mathrm{MHz}$, DMSO-d 6 ) $\delta: 143.6,138.4,135.2$ (Ar-C), $120.4,118,3,118.4,106.9(\mathrm{Ar}-\mathrm{CH}), 125.4(-\mathrm{N}-$ $\left.\underline{\mathrm{C}}\left(\mathrm{CH}_{3}\right)=\mathrm{C}-\right), \quad 125.2 \quad\left(\mathrm{H}_{2} \mathrm{C}=\underline{\mathrm{C}}\left(\mathrm{CH}_{3}\right)-\right), \quad 105.8$ $\left(\mathrm{H}_{2} \mathrm{C}=\mathrm{C}\left(\mathrm{CH}_{3}\right)^{-}\right), 74.3\left(-\mathrm{N}-\mathrm{C}\left(\mathrm{CH}_{3}\right)=\underline{\mathrm{C}}-\right), 27.1,21.5$ $\left(-\mathrm{CH}_{3}\right)$.

7,7,9-Trimethyl-6,7-dihydro-1H-pyrazolo[3,4f] quinoline $\mathbf{V}$, method $\mathbf{c}$ : a mixture of ( $1 \mathrm{~g}$, $7.220 \mathrm{mmol}$ ) of 6-aminoindazole, mesityl oxide $(0.737 \mathrm{~g}, 7.220 \mathrm{mmol})$, iodine $5 \mathrm{~mol} \%$ (0.361 $\mathrm{mmol}, 0,091 \mathrm{~g})$ and $100 \mathrm{~mL}$ of acetone, $1.130 \mathrm{~g}$, $74 \%$, m.p. $190^{\circ} \mathrm{C},{ }^{1} \mathrm{H}-\mathrm{NMR}\left(300 \mathrm{MHz}, \mathrm{DMSO}-\mathrm{d}_{6}, \delta\right.$, ppm): $12.06(1 H, \mathrm{~s}), 7.69(1 H, \mathrm{~s}), 7.28(1 H, \mathrm{~d}, J$ $=8.4 \mathrm{~Hz}) 6.48(1 \mathrm{H}, \mathrm{d}, J=8.5 \mathrm{~Hz}), 6.16(1 \mathrm{H}, \mathrm{s})$, $5.10(1 H, \mathrm{~s}) ; 2.25(3 H, \mathrm{~s}), 1.21(6 H, \mathrm{~s}) .{ }^{13} \mathrm{C}-\mathrm{NMR}$ $\left(100 \mathrm{MHz}, \mathrm{DMSO}-\mathrm{d}_{6}\right) \delta: 143.5,142.2,138.6$, 127.3, 125.4 (Ar-C), 120.4, 117.84, 116.9, 110.1 $(\mathrm{Ar}-\mathrm{CH}), 50.7\left(-\mathrm{NH}-\mathrm{C}\left(\mathrm{CH}_{3}\right)_{2}\right), 29.8\left(2 \mathrm{x}-\mathrm{CH}_{3}\right), 21.3$
$\left(-\mathrm{CH}_{3}\right)$.

\section{1,7,7,9-Tetramethyl-6,7-dihydro-1H- pyrazolo[3,4-f] quinoline VI, method a: $(0.147$} $\mathrm{g}, 1 \mathrm{mmol})$ of 1 -methyl-6-aminoindazoline in 10 $\mathrm{mL}$ of acetone, with $5 \mathrm{~mol} \%$ of iodine give $49 \%$, $0.136 \mathrm{~g}$. A mixture of 1-methyl 6-aminoindazole $(0.195 \mathrm{~g}, 1.326 \mathrm{mmol})$, mesityl oxide $(0.131 \mathrm{~g}$, $1.326 \mathrm{mmol})$, in $30 \mathrm{~mL}$ of methanol, acetone and glacial acetic acid $(1 / 1 / 1 \mathrm{v} / \mathrm{v} / \mathrm{v})$, activated by 10 mol\% Pd/C, 0.135 g, 48\%, m.p. $92^{\circ} \mathrm{C},{ }^{1} \mathrm{H}-\mathrm{NMR}$ $\left(300 \mathrm{MHz}, \mathrm{DMSO}-\mathrm{d}_{6}, \delta, \mathrm{ppm}\right): 8.16(1 \mathrm{H}, \mathrm{s}), 7.68$ $(1 H, d, J=7.5 \mathrm{~Hz}), 6.79(1 \mathrm{H}, \mathrm{d}, \mathrm{J}=8.5 \mathrm{~Hz}), 5.40$ $(1 H, \mathrm{~d}, J=4.7 \mathrm{~Hz}), 4.23(3 \mathrm{H}, \mathrm{s}), 2.74(3 \mathrm{H}, \mathrm{s})$, $1.58(6 H, s) .{ }^{13} \mathrm{C}-\mathrm{NMR}\left(100 \mathrm{MHz}, \mathrm{DMSO}-\mathrm{d}_{6}\right) \delta:$ 144.9, 144.3, 139.0, 136.9, 133.9 (Ar-C), 120.9, 117.2, 112.1, $99.9(\mathrm{Ar}-\mathrm{CH}), 50.9\left(-\mathrm{NH}-\mathrm{C}\left(\mathrm{CH}_{3}\right)_{2}\right)$, $39.3\left(>\mathrm{N}-\mathrm{CH}_{3}\right), 29.4\left(2 \mathrm{x}-\mathrm{CH}_{3}\right), 27.5\left(-\mathrm{CH}_{3}\right)$.

\section{Condensation of aminoindole into quinoline In the presence of acetone}

A dry $250 \mathrm{~mL}$ bi-necked flask was charged with $1.45 \mathrm{~g}(10.98 \mathrm{mmol})$ of 5 -aminoindole, with $5 \mathrm{~mol}$ $\%(0.14 \mathrm{~g}, 0.549 \mathrm{mmol})$ of iodine, into a solution of $100 \mathrm{~mL}$ of acetone (variable quantity according to the number of moles of amine used). The solution is carried under reflux for 3 hours. After evaporation, the residue is purified by chromatography on the column, eluent: $\mathrm{CH}_{2} \mathrm{Cl}_{2} / \mathrm{n}$ pentane $(1 / 1 \mathrm{v} / \mathrm{v})$. Compound II is isolated with a $42 \%$ yield, $0.98 \mathrm{~g}$.

\section{In the presence of mesityl oxide}

A dry $250 \mathrm{~mL}$ bi-necked flask was charged with an equimolar mixture of 5 -aminoindole $(0.265 \mathrm{~g}$, $2.023 \mathrm{mmol})$ and of mesityl oxide $(0.198 \mathrm{~g}, 2.023$ $\mathrm{mmol})$ with $5 \mathrm{~mol} \%$ of iodine $(0.026 \mathrm{~g}, 0.101$ $\mathrm{mmol}$ ), in solution in $50 \mathrm{~mL}$ of acetone. The solution is carried under reflux for 3 hours. After filtration and evaporation, the residue is purified by chromatography on the column, eluent: $\mathrm{CH}_{2} \mathrm{Cl}_{2} / \mathrm{n}$ pentane $(1 / 1 \mathrm{v} / \mathrm{v})$. Compound II is isolated with a $50 \%$ yield, $0.215 \mathrm{~g}$.

\section{7,7,9-Trimethyl-6,7-dihydro-3H-pyrrolo[3,2-} f] quinoline II, m.p. $118^{\circ} \mathrm{C},{ }^{1} \mathrm{H}-\mathrm{NMR}$ (300 $\mathrm{MHz}$, DMSO- $_{6}$, delta, ppm): $10.71(1 \mathrm{H}, \mathrm{s}), 7.14$ $(1 H, d, J=2.3 \mathrm{~Hz}), 7.04(1 \mathrm{H}, \mathrm{d}, J=8.3 \mathrm{~Hz}), 6.48$ $(1 H, \mathrm{~d}, \mathrm{~J}=8.5 \mathrm{~Hz}), 6.44(1 \mathrm{H}, \mathrm{sbr}), 5.17(1 H, \mathrm{~s})$, $2.20(3 H, s), 1.17(6 H, s) .{ }^{13} \mathrm{C}-N M R(100 \mathrm{MHz}$, DMSO-d 6 ) $\delta: 137.5,130.9,130.1,127.3,124.7$ (Ar-C), 124.5, 113.2, 111.7, 110.9, $100.9(\mathrm{Ar}-\mathrm{CH})$, $50.6\left(-\mathrm{NH}-\mathrm{C}\left(\mathrm{CH}_{3}\right)_{2}\right), 29.4\left(2 \mathrm{x}-\mathrm{CH}_{3}\right), 22.3\left(-\mathrm{CH}_{3}\right)$.

\section{RESULTS AND DISCUSSION}

\section{Test of Catalysts}

The treatment of 5-aminoindazole with different catalysts in acetone under reflux and microwave afforded to the corresponding quinoline III in good yield (Scheme 1). 
Our first study focused on the absence of a catalyst; any progress was found neither under reflux nor a microwave system (Table 1, Entry 1). The same reaction was carried out with iodine in different amounts $5 \mathrm{~mol} \%, 10 \mathrm{~mol} \%$, and $20 \mathrm{~mol}$ $\%$, the given result in yield is the same $45 \%$ (Table 1, Entry 2), showing that a higher amount of catalyst has no influence on the reaction. Some transition metals were also used to catalyze our reaction under the same conditions, copper (CuI,
$\left.\mathrm{CuCl}, \mathrm{CuSO}_{4}\right)$, iron $\left(\mathrm{FeCl}_{3}\right)$, manganese $(\mathrm{MnO})$, and bismuth $\left(\mathrm{BiCl}_{3}\right)$ in their salt form give fewer interesting results (0-25\%) as shown in (Table 1 , Entry 3-8). $\mathrm{ZnCl}_{2}$ performs the reaction as iodine does and led us to the desired product III with a $45 \%$ yield (Table 1, Entry 10). I 2 was chosen instead of $\mathrm{ZnCl}_{2}$ to catalyze the reaction because of its non-toxic, inexpensive, and eco-friendly nature (22-27).

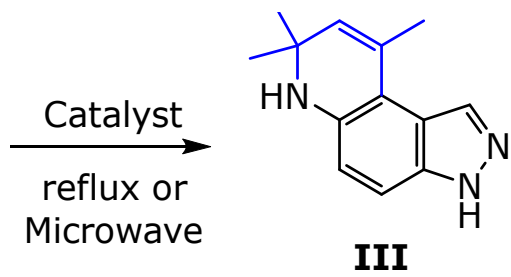

Scheme 1: Cyclization of 5-aminoindazole with acetone under different conditions.

Table 1: Optimization of yield for III using different catalysts under reflux.

\begin{tabular}{cccc}
\hline Entry & Catalyst & Time (h) & yield\% $^{\mathrm{b}}$ \\
\hline $\mathbf{1}^{\mathrm{a}}$ & - & 3 & $\mathrm{ND}^{\mathrm{a}}$ \\
$\mathbf{2}^{\mathrm{a}}$ & $\mathbf{I}_{\mathbf{2}}$ & $\mathbf{3}$ & $\mathbf{4 5}^{\mathrm{a}}$ \\
$\mathbf{3}$ & $\mathrm{CuI}$ & 3 & Trace \\
$\mathbf{4}$ & $\mathrm{CuCl}$ & 3 & 20 \\
$\mathbf{5}$ & $\mathrm{CuSO}_{4}$ & 3 & $\mathrm{ND}$ \\
$\mathbf{6}$ & $\mathrm{BiCl}_{3}$ & 3 & 25 \\
$\mathbf{7}$ & $\mathrm{FeCl}_{3}$ & 3 & 25 \\
$\mathbf{8}$ & $\mathrm{MnO}$ & 3 & $\mathrm{ND}$ \\
$\mathbf{9}$ & $\mathrm{PdCl}_{2}$ & 3 & 23 \\
$\mathbf{1 0}$ & $\mathbf{Z n C l}_{\mathbf{2}}$ & $\mathbf{3}$ & $\mathbf{4 5}$ \\
\hline
\end{tabular}

${ }^{\text {a }}$ Reaction tested under microwave system $\left(30 \mathrm{~min}, 150{ }^{\circ} \mathrm{C}, 400 \mathrm{~W}\right),{ }^{\mathrm{b}}$ isolated yield, ND: not detected

\section{Optimization of the conditions for microwave irradiation}

The choice of the optimal condition reaction under microwave irradiation was studied, the same substrate has been condensed in the presence of acetone catalyzed by iodine, starting with temperature from $100{ }^{\circ} \mathrm{C}$ during $30 \mathrm{~min}$ of reaction, we observed a formation of compound III with $20 \%$ of yield, after increasing the heating we reached $150{ }^{\circ} \mathrm{C}$ corresponding to $45 \%$ of yield, some impurities were spotted above this temperature, we then fixed it and changed the time of reaction, after 5 min under irradiation no evolution was observed, the structure III begins to be formed from the 15th min, the isolated yield indicates $12 \%$ and start increasing until $45 \%$ and stabilizes after 30 min of reaction. The reaction under reflux was privileged compared to microwave irradiation because it requires less drastic conditions insight of the power and temperature needed to get our desired structures.

\section{Formation of quinolines}

Having noted, we observed a transformation of 5amino-1-methylindazole and the 5-aminoindole bunged with the free air into quinoline $\mathbf{I}$ and II (Figure 2).

Test reaction of condensation on the products transformed lead to the same structure of quinoline $\mathbf{I}$ and $\mathbf{I I}$ in both cases, even with acetone or mesityl oxide.<smiles>CC1=CC(C)(C)Nc2ccc3c(cnn3C)c21</smiles><smiles>CC1=CC(C)(C)Nc2ccc3[nH]ccc3c21</smiles>

Figure 2. Quinolines I and II formed from 5amino-1-methylindazole and the 5-aminoindole respectively. 
After 3 hours in refluxing the 5-amino-1methylindazole with acetone in the catalytic medium of iodine, we observed the formation of the product I with a yield of $34 \%$. However, the 5amino-1- methylindazole treated with mesityl oxide in the presence of iodine led to a similar product of structure I with a yield of $97 \%$ (Table 2, Entry 1). After carrying out the proton and carbon 13 NMR spectra, a study of spectral fragmentation of mass shows the presence of a molecular mass of 227 amu and a chemical ionization of the peak $[\mathrm{M}+1]+$ is equal to 228 amu $(\mathrm{M}+\mathrm{H}+)$ and two other significant peaks of fragmentation $M / Z=29$ for ion $\mathrm{NCH}_{3}$ ] + and $\mathrm{M} / \mathrm{Z}=41$ for ion $\left.\mathrm{HCN}\right]+$. The addition of the 5-aminoindole with acetone in the presence of a catalytic quantity of iodine under reflux led to the same structure II, which is obtained with a reaction yield of $42 \%$. However, the action of mesityl oxide on the 5-aminoindole, under the same conditions, gives us the structure II with a yield of $50 \%$, as shown in (Table 2 (Entry 2). We realized that the reaction of 5aminoindazole in the presence of acetone produces the compound III with $45 \%$ of yield (Table 2,
Entry 3), then we observed the formation of another product IV in addition to our predicted one III by using mesityl oxide under identical conditions, the two current structures were formed in competition with less difference in yield $24 \%$ and $28 \%$ respectively (Table 2, Entries 3-4). For this phenomenon, two mechanisms were suggested, a different attack of the mesityl oxide on 5- aminoindazole (Scheme 3,4). However, the condensation of the 6-aminoindazole with mesityl oxide led to the compound $\mathbf{V}$ with an output of $74 \%$, illustrating a more interesting result against the condensation with acetone which gives a $27 \%$ yield (Table 2, Entry 5). The structure VI was formed with $49 \%$ in yield under the same conditions as the previously formed quinolines; in order the increase this last and to observe the best condensation, the 6-amino-1-methylindazole condenses with mesityl oxide in the presence of a mixture of the solvent of $\mathrm{CH}_{3} \mathrm{OH} / \mathrm{CH}_{3} \mathrm{COCH}_{3} / \mathrm{CH}_{3} \mathrm{CO}_{2} \mathrm{H}$ catalyzed by $\mathrm{Pd} / \mathrm{C}$ (12), the competitor's condition shows any evolution in yield and give $48 \%$ of quinoline VI (Table 2, Entry 6).

Table 2. Formation of quinoline derivatives using acetone and mesityl oxide.

\begin{tabular}{|c|c|c|c|}
\hline Entry ${ }^{a}$ & Amine & Product & $\begin{array}{l}\text { Yield using } \\
\text { acetone }\end{array}$ \\
\hline
\end{tabular}

1<smiles>Cn1ncc2cc(N)ccc21</smiles>

$2^{c}$<smiles>Nc1ccc2[nH]ccc2c1</smiles>

$3^{c}$<smiles>Nc1ccc2[nH]ncc2c1</smiles>

4<smiles>CC1=CC(C)(C)Nc2ccc3c(cnn3C)c21</smiles>

$34 \%$

$97 \%$

$\mathbf{I}$<smiles>CC1=CC(C)(C)Nc2ccc3[nH]ccc3c21</smiles>

$42 \%{ }^{c}$

$50 \%$

II<smiles>CC1=CC(C)(C)Nc2ccc3[nH]ncc3c21</smiles>

$45 \%{ }^{c}$

$28 \%$

\section{III}<smiles>Nc1ccc2[nH]ncc2c1</smiles> 
<smiles>C=C(C)C=C(C)Nc1ccc2[nH]ncc2c1</smiles>

IV $5^{\mathrm{c}}$<smiles>Nc1ccc2cn[nH]c2c1</smiles><smiles>Cn1ncc2ccc(N)cc21</smiles><smiles>CC1=CC(C)(C)Nc2ccc3cn[nH]c3c21</smiles>

v<smiles>CC1=CC(C)(C)Nc2ccc3cnn(C)c3c21</smiles>

$27 \%{ }^{c}$

$74 \%$

$49 \%$

$48 \%$ d

VI

${ }^{a}$ Reaction condition: solvent: acetone, reflux (3h), $5 \mathrm{~mol} \% \mathrm{I}_{2}$ as the catalyst.

${ }^{b}$ Isolated yield, ND: not detected.

${ }^{\mathrm{c}}$ Reaction was also tested under microwave irradiation $\left(150{ }^{\circ} \mathrm{C}, 400 \mathrm{~W}, 30 \mathrm{~min}\right)$.

${ }^{d}$ Reaction condition : solvent : $\mathrm{CH}_{3} \mathrm{OH} / \mathrm{CH}_{3} \mathrm{COCH}_{3} / \mathrm{CH}_{3} \mathrm{CO}_{2} \mathrm{H}$, reflux (3h), 10 mol\% Pd / C (12) as catalyst.

\section{Proposed mechanisms}

The mechanism proposed is shown in (Scheme 2), iodine participates in equilibrium form of acetone into enol, the amine attacks the carbonyl functional group then a Diels-Alder reaction naturally takes place spawning dehydration. Finally, structure $\mathbf{I}$ is produced following a cyclization step.

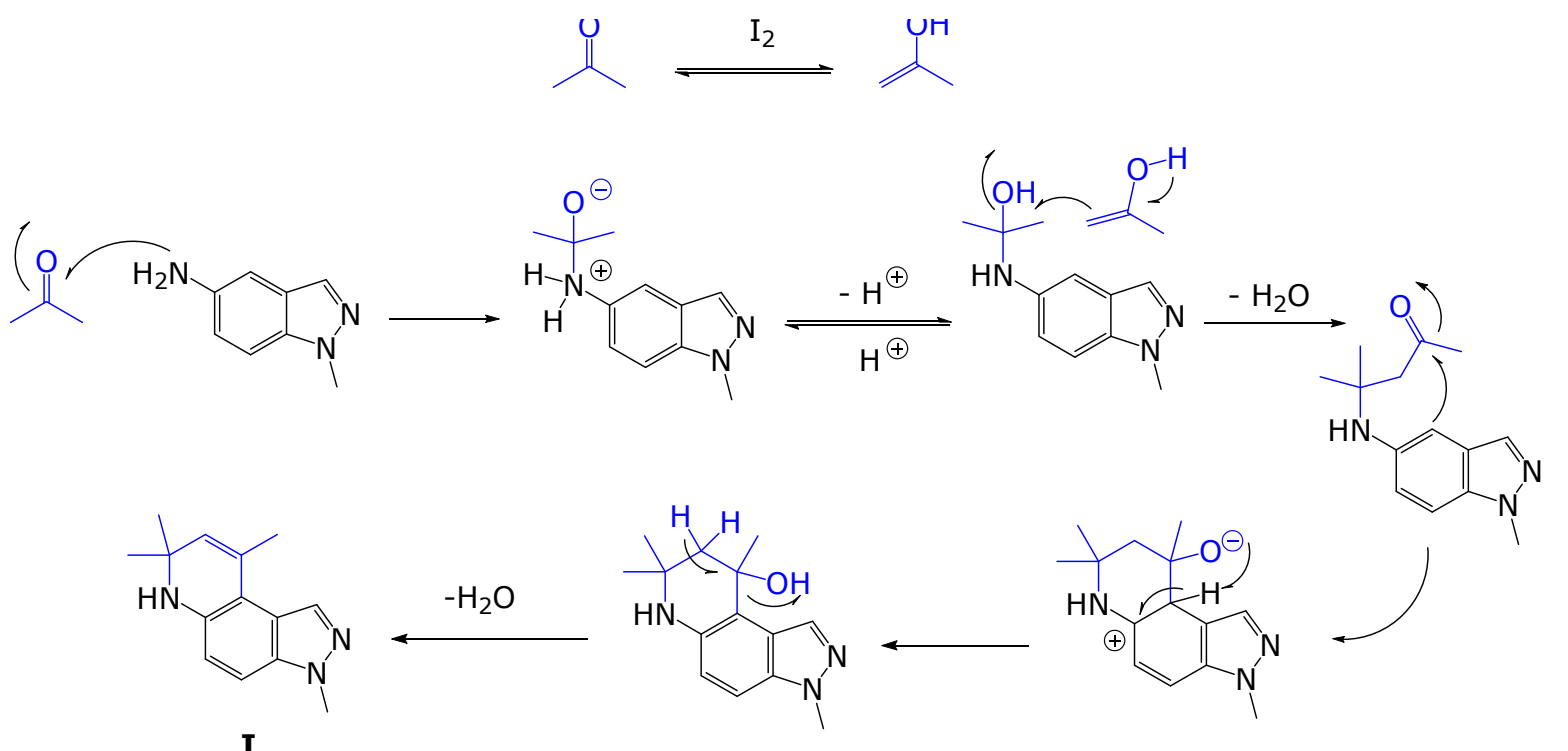

Scheme 2. The suggested mechanism for obtaining structure I using acetone.

The two structures IV and $\mathbf{V}$ were formed because of the considerable difference of amine's attack on mesityl oxide. Structure IV was undoubtedly formed when the amine reacts favorably with the carbonyl function disadvantaging the cyclization (Scheme 3). 
Attack at 1, 2

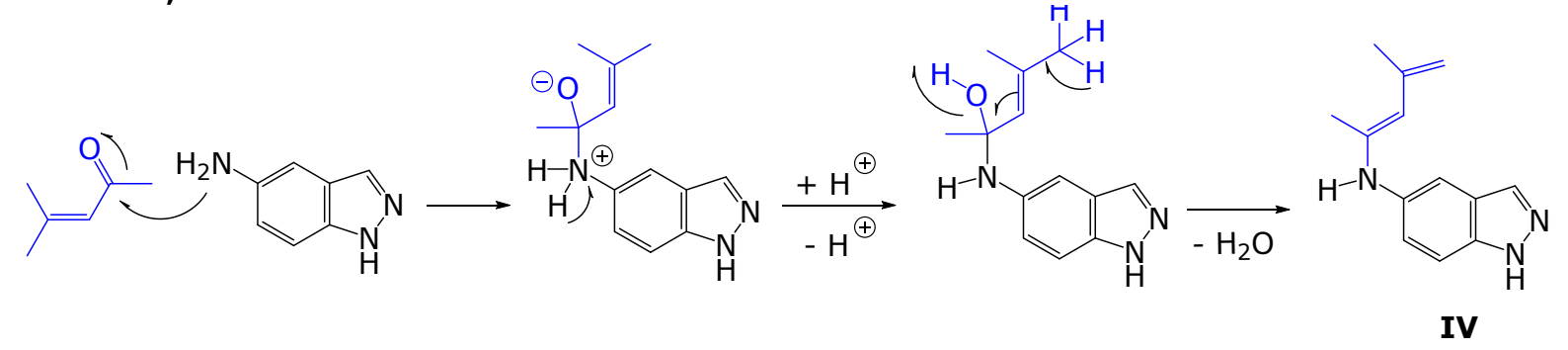

Scheme 3. The mechanism suggested obtaining structure IV using mesityl oxide.

On the other hand, the amine reacts correctly with the aliphatic alkene vacating place to the cyclization naturally done by the carbonyl function (Scheme 4).

\section{Attack at 1, 4}

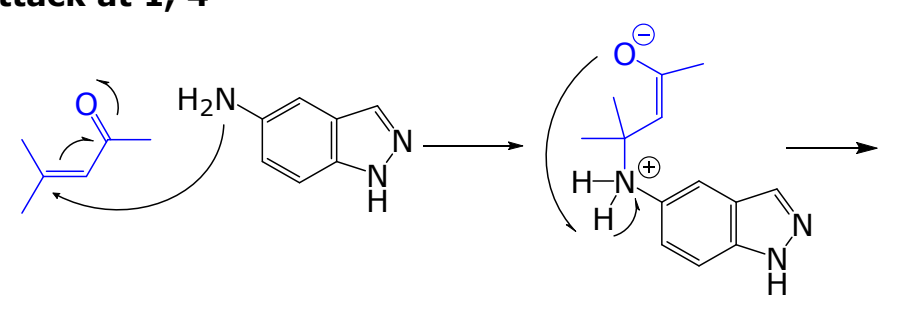<smiles>CO/C(C)=C\C(C)(C)Nc1ccc2[nH]ncc2c1</smiles><smiles>CCC(=O)C1CCCCCC1(C)C(C)(C)Nc1ccc2[nH]ncc2c1</smiles>

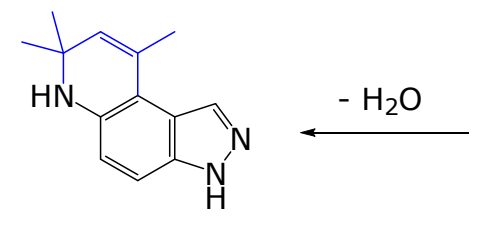

III<smiles></smiles>

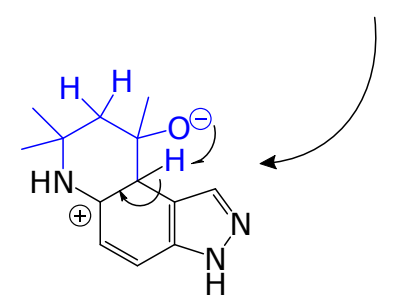

Scheme 4. The mechanism suggested obtaining structure III using mesityl oxide.

\section{CONCLUSION}

In conclusion, a simple and eco-friendly approach has been demonstrated to synthesize different quinolines with a different yield up to $97 \%$ starting from indazolic and indolic structures by condensation using acetone and mesityl oxide in a catalytic medium of iodine, the conventional way and the microwave system of the condensation reaction generate the same results, on this cause that the reflux reaction was chosen as the leading precursor to obtain our final structures in order to avoid the energy consumption at elevated temperature which can assist polymerization.

\section{ACKNOWLEDGEMENTS}

The authors are grateful to Prof Dr.El Abed, university Oran 1, Algeria. Furthermore, we thank the Algerian "Ministry of Higher Education and scientific research and DGRSDT" for financial support.

\section{REFERENCES}

1. Kang YK, Shin KJ, Yoo KH, Seo KJ, Hong CY, Lee $\mathrm{C}-\mathrm{S}$, et al. Synthesis and antibacterial activity of new carbapenems containing isoxazole moiety. Bioorganic \& Medicinal Chemistry Letters. 2000 Jan;10(2):95-9. DOI: https://doi.org/10.1016/S0960-894X(99)00646-0.

2. Kochetkov NK, Sokolov SD. Recent developments in isoxazole chemistry. In: Advances in Heterocyclic Chemistry [internet]. Elsevier; 1963 [cited 2021 jun 4]. p. 365-422. ISBN: 978-0-12020602-5.

3. Gezegen $H$, Gürdere MB, Dinçer A, Özbek $O$, Koçyiğit ÜM, Taslimi $P$, et al. Synthesis, molecular docking, and biological activities of new cyanopyridine derivatives containing phenylurea. Arch Pharm. 2021 Apr;354(4):2000334. DOI: https://doi.org/10.1002/ardp.202000334.

4. Sironi M, Massimiliano I, Transidico $P$, Pinza $M$, Sozzani S, Mantovani A, et al. Differential effect of 
benzydamine on pro- versus anti-inflammatory cytokine production: Lack of inhibition of interleukin-10 and interleukin-1 receptor antagonist. Int J Clin Lab Res. 2000 Mar;30(1):179. DOI: https://doi.org/10.1007/s005990070028.

5. Párkányi C, Schmidt DS. Synthesis of 5-chloro2-methyl-3-(5-methylthiazol-2-yl)-4(3 h )quinazolinone and related compounds with potential biological activity. Journal of Heterocyclic Chemistry. 2000 Jul;37(4):725-9. DOI: https://doi.org/10.1002/jhet.5570370409.

6. Xiao K, Zhang H-J, Xuan L-J, Zhang J, Xu Y-M, Bai D-L. Stilbenoids: Chemistry and bioactivities. In: Studies in natural products chemistry [internet]. Elsevier; 2008 [cited 2021 jun 4]. p. 453-646. ISBN: 978-0-444-53180-3.

7. Özbek O, Gürdere MB. Synthesis and anticancer properties of 2-aminothiazole derivatives. Phosphorus, Sulfur, and Silicon and the Related Elements. 2021 May 4;196(5):444-54. DOI: https://doi.org/10.1080/10426507.2020.1871347.

8. Özbek O, Usta NC, Gürdere MB, Aslan ON, Budak Y, Ceylan M. Synthesis and antibacterial screening of novel 2-(4-(aryl) thiazol-2-yl)3a,4,7,7a-tetrahydro-1 H -4,7-ethanoisoindole1,3(2 H )-dione derivatives. Phosphorus, Sulfur, and Silicon and the Related Elements. 2017 Oct 3;192(10):1153-7.

DOI: https://doi.org/10.1080/10426507.2017.1354209.

9. Poursattar Marjani A, Khalafy J, Salami F, Mohammadlou M. Tin(II) chloride catalyzed synthesis of new pyrazolo[5,4-b]quinolines under solvent-free conditions. Synthesis. 2015 Jun;47(11): 1656-60.

https://doi.org/10.1055/s-0034-1380189.

10. Edwards JP, Ringgenberg JD, Jones TK. Lewisacid catalyzed reaction of 2-isopropenylaniline with ketones: Improved synthesis of 2,2,4trisubstituted 1,2-dihydroquinolines. Tetrahedron Letters. 1998 Jul;39(29):5139-42. DOI: https://doi.org/10.1016/S0040-4039(98)01010-7.

11. Leis J. Conformational dynamics and equilibria in amides [PhD thesis]. [Tartu, Estonia]: University of Tartu; 1998.

12. Manske RHF, Kulka M. The Skraup synthesis of quinolines. In: Organic Reactions [internet]. Hoboken, NJ, USA. p. 59-98. ISBN: 978-0-47126418-7.

13. Theoclitou M-E, Robinson LA. Novel facile synthesis of $2,2,4$ substituted 1,2dihydroquinolines via a modified Skraup reaction. Tetrahedron Letters. 2002 May;43(21):3907-10.
DOI: https://doi.org/10.1016/S00404039(02)00614-7.

14. Walter $H$, Sauter $H$, Winkler $T$. Eine neue einfache synthese spirocyclischer $1 \mathrm{H}$-chinolinderivate. Helv Chim Acta. 1992 Jun $24 ; 75(4): 1274-80$. https://doi.org/10.1002/hlca.19920750428.

15. Li X, Mao Z, Wang Y, Chen W, Lin X. Molecular iodine-catalyzed and air-mediated tandem synthesis of quinolines via three-component reaction of amines, aldehydes, and alkynes. Tetrahedron. 2011 May;67(21):3858-62. DOI: https://doi.org/10.1016/j.tet.2011.03.087.

16. Hamann LG, Winn DT, Pooley CLF, Tegley CM, West SJ, Farmer LUCJ, ET AL. Nonsteroidal progesterone receptor antagonists based on a conformationally-restricted subseries of 6-aryl-1,2dihydro-2,2,4-trimethylquinolines. Bioorganic \& Medicinal Chemistry Letters. 1998 Oct; 8(19):2731-6. DOI: https://doi.org/10.1016/S0960-894X(98)00482-X.

17. Wu Y-C, Liu L, Li H-J, Wang D, Chen Y-J. Skraup-Doebner-Von Miller quinoline synthesis revisited: Reversal of the regiochemistry for $\gamma$-aryl$\beta, \gamma$-unsaturated a-ketoesters. J Org Chem. 2006 Aug;71(17):6592-5.

DOI: https://doi.org/10.1021/jo060290n.

18. Eisch JJ, Dluzniewski T. Mechanism of the Skraup and Doebner-Von Miller quinoline syntheses. Cyclization of alpha,beta-unsaturated n-aryliminium salts via 1,3-diazetidinium ion intermediates. J Org Chem. 1989 Mar;54(6):126974. DOI: https://doi.org/10.1021/jo00267a010.

19. Johnson JV, Rauckman BS, Baccanari DP, Roth B. 2,4-Diamino-5-benzylpyrimidines and analogs as antibacterial agents. 12. 1,2Dihydroquinolylmethyl analogs with high activity and specificity for bacterial dihydrofolate reductase. J Med Chem. 1989 Aug;32(8):1942-9. DOI: https://doi.org/10.1021/jm00128a042.

20. Wang $W$, Yin $M-Y$, Zhang $M-M$, Wang X-S. Iodine-catalysed synthesis of thiopyrano[3,4c]quinoline derivatives via imino-Diels-Alder reaction. Journal of Chemical Research. 2012 Jun;36(6):318-21.

DOI: https://doi.org/10.3184/174751912X13352797144 052.

21. Dayal N, Wang M, Sintim HO. HSD1787, a tetrahydro-3 $\mathrm{H}$-pyrazolo[4,3- $\mathrm{f}$ ]quinoline compound synthesized via Povarov reaction, potently inhibits proliferation of cancer cell lines at nanomolar concentrations. ACS Omega. 2020 Sep 22;5(37):23799-807.
DOI: 
https://doi.org/10.1021/acsomega.0c03001.

22. Wang G-W, Gao J. Selective formation of spiro dihydrofurans and cyclopropanes through unexpected reaction of aldehydes with 1,3dicarbonyl compounds. Org Lett. 2009 Jun 4;11(11):2385-8.

https://doi.org/10.1021/ol900451d.

23. Mal D, De SR. Total synthesis of euplectin, A natural product with a chromone fused indenone. Org Lett. 2009 Oct 1;11(19):4398-401. DOI: https://doi.org/10.1021/ol901817r.

24. Parvatkar PT, Parameswaran PS, Tilve SG. An expeditious i 2 -catalyzed entry into $6 \mathrm{H}$ indolo[2,3- b ]quinoline system of cryptotackieine. J Org Chem. 2009 Nov 6;74(21):8369-72. DOI: https://doi.org/10.1021/jo901361x.

25. Zeng L-Y, Cai C. Iodine catalyzed one-pot multicomponent synthesis of a library of compounds containing tetrazolo[ $1,5-$ a $]$ pyrimidine core. J Comb Chem. 2010 Jan 11;12(1):35-40. DOI: https://doi.org/10.1021/cc9000983.

26. Das B, Balasubramanyam $P$, Krishnaiah $M$, Veeranjaneyulu B, Reddy GC. Iodine-catalyzed efficient hydrophosphonylation of $\mathrm{N}$-tosyl aldimines. J Org Chem. 2009 Jun 5;74(11):43935. DOI: https://doi.org/10.1021/jo9003162.

27. Cho C-H, Neuenswander B, Lushington GH, Larock RC. Solution-phase parallel synthesis of a multi-substituted benzo[ $b$ ]thiophene library. ] COMB CHEM. 2009 Sep 14;11(5):900-6. DOI: https://doi.org/10.1021/cc9000604. 
